Ann. Biol. anim. Bioch. Biophys., 1979, 19 (2 A), 343-353.

\title{
Metabolic implications of methionine excess. Effects of methionine excess, dietary protein, fasting, cortisol and insulin on certain hepatic enzyme activities involved in transsulfuration, glycolysis, gluconeogenesis and lipogenesis in adapted adult rats.
}

\author{
par D. FAU, M. CHANEZ, Brigitte BOIS-JOYEUX, J. PERET \\ Centre de Recherches sur la Nutrition du C.N.R.S. \\ 92190 Meudon-Bellevue, France.
}

Summary. Three experiments were carried out to compare the influence of nutritional (fasting, high protein diet and methionine excess) and hormonal (cortisol and insulin) factors on the activities of some enzymes involved in transsulfuration, glycolysis, gluconeogenesis, protein catabolism and lipogenesis in adapted adult rats. The activity of methionine-adenosyl tranferase seemed to depend directly on the amount of methionine ingested, that of cystathionine synthase was responsive to hormonal factors, and the cystathionase responded mainly to nutritional factors. When rats ingested excess methionine, pyruvate kinase activity decreased and malic enzyme activity was strongly reduced, while all the enzymes involved in lipogenesis maintained their normal activities. Hypotheses concerning the latter phenomenon are discussed. Under our experimental conditions, dietary factors had stronger and more persistent effects than injected hormones on both the specific and the nonspecific metabolic pathways studied.

Many authors have studied this amino acid in mammals from several perspectives (protein synthesis : Kato et al., 1966 ; sulfur metabolism : Finkelstein et al., 1974 ; methyl metabolism in relation to folate and $C_{I}$ units : Krebs ef al., 1976). The metabolic implications of an excessive methionine intake have been investigated to better understand the transsulfuration mechanism, but these studies were limited in scope (Finkelstein, 1967 ; Pan ef al., 1971).

Daniel and Waisman (1969) were the only authors to study the adaptation of rats to a dietary excess of methionine, and their work was restricted to the catabolic pathway of this amino acid. Our purpose was to compare the effects of nutritional (fasting, high protein diet and methionine excess) and hormonal (cortisol and insulin) factors on the activities of enzymes specifically involved in methionine metabolism. At the same time, we compared the effects of methionine excess and of other nutritional factors on energy metabolism by examining the activities of some enzymes of glyco- 
lysis, gluconeogenesis and lipogenesis, since ATP is implicated in the first step of methionine catabolism.

For this work, we used adapted adult male rats; the adaptation period will be reported separately in a subsequent publication.

\section{Materials and methods}

Animals and experimental procedures. - Three different experiments were carried out using 122 Wistar CF young adult male rats 8 weeks old and weighing between 180 and $200 \mathrm{~g}$. They were housed in individual cages and maintained under controlled conditions of both temperature $\left(22 \pm 2^{\circ} \mathrm{C}\right.$ ) and lighting (light from 07:00 to 19:00 hrs).

Diets. The diets fed ad libitum had the following compositions $(\mathrm{g} / 100 \mathrm{~g}$ diet) : casein ( 80 p. 100 protein) either 12.5 or 63.0 (i. e. 10.0 and 50.0 protein) with (or without) DL-methionine 2.0 ; sucrose 10.0, groundnut oil 8.0, salt mix 4.0 (Hubbel et al., 1937), vitamin mix 1.0 (Peref ef al., 1973) powdered cellulose 2.0, starch to complete $100 \mathrm{~g}$. The 10 and 50 p. 100 casein diets contained, respectively, 0.30 and 1.50 p. 100 methionine in protein, the imbalanced diets had 2.30 and 3.50 p. 100 of total methionine.

Experiment 1. Fasting. - Twenty animals were fed a diet containing 10 p. 100 casein protein for 10 days. They were then weighed and divided into 4 groups of 5 animals each, which were killed by decapitation at 0 hour (control) and after 24, 48 and 72 hrs of fasting.

Experiment 2. Nutritional factors. - Thirty-two rats were fed a diet containing 10 p. 100 casein protein for 10 days. They were divided into 4 groups of 8 animals each, and fed diets containing either 10 or 50 p. 100 casein protein, with or without 2 p. 100 DLmethionine. After 21 days, the rats were weighed and killed by decapitation between 10:00 and 11:00 hrs. The livers were removed and stored at $-80^{\circ} \mathrm{C}$.

Experiment 3. Hormonal factors. - Seventy-two animals were fed the control diet (10 p. 100 casein protein) for 10 days, and were then divided into 4 groups and fed the same diets as in experiment 2 for 21 days. Each of these 4 groups was then subdivided into 3 groups of 6 animals each, the first one acting as a control and the other two receiving either cortisol intraperitoneally $(5 \mathrm{mg} /$ day $)$ or protamine-zinc-insulin intramuscularly ( $4 \mathrm{IU} /$ day) on the last 5 days of the experiment. At the end of the experimental period, the animals were weighed and killed by decapitation.

Enzyme assays. The activities of phosphoenolpyruvate carboxykinase (PEPCK) (EC. 4.1.1.32), acetyl-CoA-carboxylase (AcCoAcarbox) (EC.6.4.1.2) and fatty acid synthetase (FAS) * were measured using the methods of Chang and Lane (1966), Chang ef al. (1967) and Maeda ef al. (1975), respectively. The ${ }^{14} \mathrm{C}$ incorporated was measured using a Packard Tricarb liquid scintillation counter.

(*) An Ec number is not given for FAS because this enzyme represents a complex of enzymes. 
The activities of pyruvate kinase (PK) (EC.2.7.1.40), malic enzyme (ME) (EC.1.1.1.40) and glucose-6-phosphate dehydrogenase (G6PDH) (EC.1.1.1.49) were determined by the methods of Weber et al. (1965), Hsu and Lardy (1969) and Fitch et al. (1959), respectively. For serine dehydratase (Ser DH) (EC.4.2.1.13), we used the method of Fallon et al. (1966) with the incubation medium of Suda and Nakagawa (1971). The liberation of NAD+ or NADPH was measured at $37^{\circ} \mathrm{C}$ and $340 \mathrm{~m} \mu$ in a Gilford $300 \mathrm{~T}$ spectrophotometer.

The activity of ATP methionine adenosyl transferase (MAdT) (EC.2.5.1.6) was determined by using L-methionine (methyl ${ }^{14} \mathrm{C}$ ) as a substrate (Spe. Act. 0.5 micro $\mathrm{Ci}$ / micromole) (Mudd ef al., 1965). The reaction was stopped in an ice bath and the Sadenosyl methionine formed was separated from the labelled substrate on cellulose phosphate in exchange discs (P 81) (McKenzie and Gholson, 1973) prepared on the $\mathrm{H}^{+}$ form (Chou and Lombardini, 1972).

The activity of cystathionine synthase (Cysta S) (EC.4.2.1.22) was determined by using the incubation medium of Mudd et al. (1965) with L-serine-U- ${ }^{14} \mathrm{C}$ (Spe. Act. 0,1 $\mu \mathrm{ci} /$ $\mu$ mole). The labelled cystathionine formed was separated by the descending technique of paper chromatography with the following solvent : butanol-acetic acid-water $(12: 3: 5)$; unlabelled cystathionine was used as a carrier ; the spot was revealed with ninhydrin, removed and counted in the following scintillation medium : biosolvtoluene-PPO, with 3 p. 100 water.

The homoserine cleavage activity of cystathionase (Cysta t) (EC.4.4.1.1.) was colorimetrically determined by the method of Greenberg (1962).

All activities were measured in the $48,000 \mathrm{~g}$ supernate, and the protein content was determined by the Kjeldahl method $(\mathrm{N} \times 6,25)$. They were expressed as nano moles of substrate per minute per $\mathrm{mg}$ protein at $37^{\circ} \mathrm{C}$. Statistical analysis of the results was carried out as described by Snedecor (1956).

\section{Results}

\section{Experiment 1. Fasting}

Table 1 denotes the evolution of some enzyme activities during the 3 days of starvation. The progressive fall of PK (glycolysis), ME and G6PDH (furnishing NADPH for lipogenesis) was associated with a rise in PEPCK activity, which was at its maximum as early as the first day of starvation ; Ser DH activity showed a marked increase (6-fold) during the 3 days of starvation. The activity of the three enzymes of the transsulfuration pathway showed significant but smaller variations : MAdT had a total activity (expressed per $100 \mathrm{~g}$ body weight) which remained practically constant, while the activity expressed per protein in the supernate increased progressively. Cysta $S$ activity per $\mathrm{mg}$ proteins remained constant, but the total activity decreased. Cystat had an intermediary response, and the total activity fell.

\section{Experiment 2. Nutritional factors}

Figure 1 compares the effects of excess methionine and high protein. Whereas the high protein diet decreased glycolysis (PK) and increased gluconeogenesis (PEPCK), 
TABLE 1

Experiment 1, Effect of fasting on liver PK, PEPCK, ME, G6PDH, Ser DH, M Ad T, Cysta $S$ and Cysto $t$ activity $\left({ }^{1}\right)\left({ }^{2}\right)$ in rats.

\begin{tabular}{|c|c|c|c|c|c|c|c|c|}
\hline & \multicolumn{2}{|c|}{ PK } & \multicolumn{2}{|c|}{ PEPCK } & \multicolumn{2}{|c|}{ ME } & \multicolumn{2}{|c|}{ G6PDH } \\
\hline & 1 & 2 & 1 & 2 & 1 & 2 & 1 & 2 \\
\hline 10 p. 100 Casein $(5)\left({ }^{3}\right)$ & $\begin{array}{r}918^{a}\left({ }^{(4}\right) \\
\pm 49.7\end{array}$ & $\begin{array}{c}372^{a} \\
\pm 25.5\end{array}$ & $\begin{array}{r}15.2^{c} \\
\pm 1.99\end{array}$ & $\begin{aligned} & 6.03^{c} \\
\pm & 0,63\end{aligned}$ & $\begin{array}{r}117.9 a \\
\pm 14.19\end{array}$ & $\begin{array}{r}46.7 a \\
\pm 3.82\end{array}$ & $\begin{array}{r}33.2^{a} \\
\pm 1.74\end{array}$ & $\begin{array}{l}16.33^{a} \\
\pm 0,87\end{array}$ \\
\hline $24 \mathrm{~h}$ fasting (5) ... & $\begin{array}{r}838^{a b} \\
+50.9\end{array}$ & $\begin{array}{r}269 b \\
+\quad 8.4\end{array}$ & $\begin{array}{r}46.2^{a} \\
+1.97\end{array}$ & $\begin{array}{l}15.02^{a} \\
\pm 0.73\end{array}$ & $\begin{array}{c}60.9 b \\
\pm \quad 1.48\end{array}$ & $\begin{array}{r}19.8^{b} \\
\pm 0.96\end{array}$ & $\begin{array}{r}24.0^{\circ} \\
+\quad 1.18\end{array}$ & $\begin{aligned} & 9.96^{b} \\
\pm & 0.99\end{aligned}$ \\
\hline $48 \mathrm{~h}$ fasting (5). & $\begin{array}{c}549 b \\
\pm 40.3\end{array}$ & $\begin{array}{r}169 c \\
\pm 11.1\end{array}$ & $\begin{array}{r}41.19 b \\
\pm 2.78 \\
\end{array}$ & $\begin{array}{c}12.64^{b} \\
\pm 0.82 \\
\end{array}$ & $\begin{array}{r}41.3 b c \\
\pm \quad 3.14 \\
\end{array}$ & $\begin{array}{r}12.8 c \\
\pm 1.17 \\
\end{array}$ & $\begin{array}{r}19.9 b \\
+2.20 \\
\end{array}$ & $\begin{aligned} & 7.42^{c} \\
\pm & 0.83\end{aligned}$ \\
\hline $72 \mathrm{~h}$ fasting (5) & $\begin{array}{r}\quad 404 c \\
\pm 12.9\end{array}$ & $\begin{array}{r}127^{d} \\
\pm 10.7\end{array}$ & $\begin{array}{r}36.3^{b} \\
\pm 1.05\end{array}$ & $\begin{array}{c}11.32^{b} \\
\pm 0.79\end{array}$ & $\begin{array}{r}31.1 c \\
\pm \quad 1.05\end{array}$ & $\begin{array}{r}9.60 c \\
\pm 0.95\end{array}$ & $\begin{array}{r}13.8 c \\
\pm 0.90\end{array}$ & $\begin{aligned} & 4.68^{a} \\
\pm & 0.37\end{aligned}$ \\
\hline
\end{tabular}

\begin{tabular}{|c|c|c|c|c|c|c|c|c|}
\hline & \multicolumn{2}{|c|}{ Ser DH } & \multicolumn{2}{|c|}{ M Ad T } & \multicolumn{2}{|c|}{ Cysta S } & \multicolumn{2}{|c|}{ Cysta $t$} \\
\hline & 1 & 2 & 1 & 2 & 1 & 2 & 1 & 2 \\
\hline 10 p. 100 Casein $(5)\left({ }^{3}\right) \ldots$ & $\begin{aligned} & 4.93^{c} \\
\pm & 0.55\end{aligned}$ & $\begin{array}{r}2.35 c \\
+0.29\end{array}$ & $\begin{aligned} & 1.18^{c} \\
\pm & 0.04\end{aligned}$ & $\begin{aligned} & 0.594^{a} \\
+ & 0.020\end{aligned}$ & $\begin{array}{r}1.44^{a} \\
\pm 0.04\end{array}$ & $\begin{array}{r}0,68^{a} \\
+\quad 0.017\end{array}$ & $\begin{array}{r}5.80^{b} \\
\pm 0.37\end{array}$ & $\begin{aligned} & 2.92^{a} \\
\pm & 0.18\end{aligned}$ \\
\hline $24 \mathrm{~h}$ fasting (5) & $\begin{array}{l}\quad 6.61 \mathrm{c} \\
\pm 1.63\end{array}$ & $\begin{array}{r}2.70 c \\
\pm 0.67\end{array}$ & $\begin{aligned} & 1.35^{b c} \\
\pm & 0.08\end{aligned}$ & 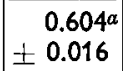 & $\begin{aligned} & 1.35 a \\
\pm & 0.06\end{aligned}$ & $\begin{array}{r}0.56^{b} \\
\pm 0.024\end{array}$ & $\begin{aligned} & 6.15^{a b} \\
\pm & 0.45\end{aligned}$ & $\begin{aligned} & 2.76^{a b} \\
\pm & 0.20\end{aligned}$ \\
\hline $48 \mathrm{~h}$ fasting (5) & $\begin{array}{c}18.58^{b} \\
\pm 2.78\end{array}$ & $\begin{array}{r}6.60^{b} \\
\pm 0.97 \\
\end{array}$ & $\begin{array}{ll} & 1.53^{a b} \\
\pm & 0.08\end{array}$ & $\begin{array}{r}0.588 a \\
\pm 0.044\end{array}$ & $\begin{aligned} & 1.30^{a} \\
\pm & 0.08\end{aligned}$ & $\begin{array}{r}0.46 c \\
\pm 0.036\end{array}$ & $\begin{array}{l}6.36^{a b} \\
0.62\end{array}$ & $\begin{aligned} & 2.46^{b} \\
\pm & 0.30\end{aligned}$ \\
\hline $72 \mathrm{~h}$ fasting (5) & $\begin{array}{r}29.15^{a} \\
\pm 1.99\end{array}$ & $\begin{array}{r}10.24 a \\
\pm 1.67\end{array}$ & $\begin{aligned} & 1.64^{a} \\
\pm & 0.08\end{aligned}$ & $\begin{aligned} & 0.579 a \\
\pm & 0.032\end{aligned}$ & $\begin{array}{l}1.31^{a} \\
\pm 0.06\end{array}$ & $\begin{array}{r}0.46^{c} \\
\pm 0.018\end{array}$ & $\begin{array}{c}7.27 a \\
\pm 0.35\end{array}$ & $\begin{array}{ll} & 2.51^{b} \\
\pm & 0.16\end{array}$ \\
\hline
\end{tabular}

Enzyme activity is expressed : $\left({ }^{1}\right)$ in nanomoles of substrate converted at $37^{\circ}$ per minute per $\mathrm{mg}$ protein $(\mathrm{N} \times 6.25) ;\left({ }^{2}\right)$ in micromoles of substrate converted per minute per $100 \mathrm{~g}$ initial body weight ; $\left({ }^{3}\right)$ Number of rats; $\left({ }^{4}\right)$ Mean \pm SEM, means followed by different letter are significantly different $(P<0.05))$; all comparisons are vertical.

a 2 p. 100 excess of methionine ingested for 3 weeks had no effect on PEPCK and only slightly reduced the activity of PK.

High G6PDH activities were found with the 50 p. 100 casein diets, but this effect was not associated with a fall in ME activities. Methionine had no effect on G6PDH, but lowered ME activity to the same extent as the high protein diet; these two effects were not cumulative.

The activities of lipogenic enzymes (AcCoAcarbox and FAS) were strongly reduced by the 50 p. 100 casein diet, whereas excess methionine ingested for 3 weeks did not increase these activities.

Ser DH showed highly elevated activities in animals fed the high protein diet; upon adaptation, excess methionine had no effect on either group of animals.

The three transsulfuration enzymes studied differed in response to these nutri- 

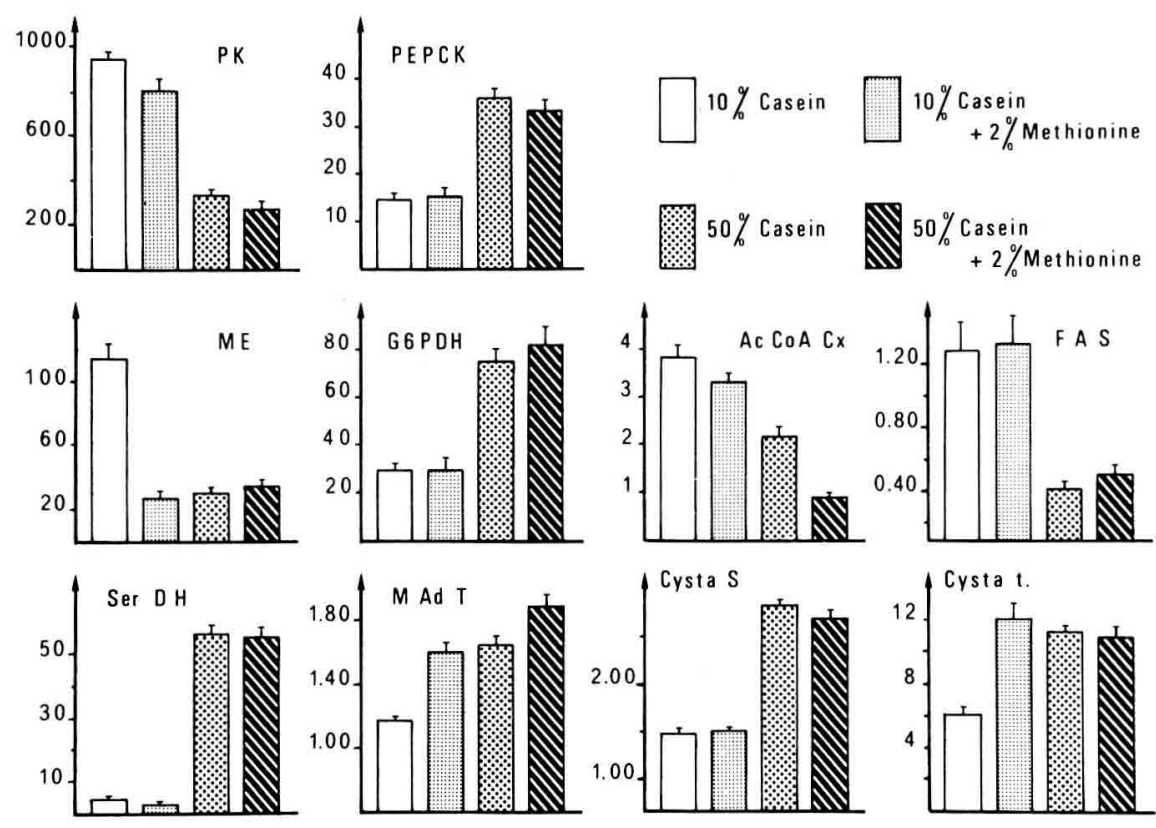

FIG. 1. - Hepatic enzyme activifies following high casein and/or methionine excess ingesfed for three weeks. Values for each group ( 8 rats) represent means $\pm S E M$. Enzyme activities are expressed in nanomoles of substrate converted per minute per $\mathrm{mg}$ protein at $37^{\circ} \mathrm{C}$.

tional factors ; MAdT activity was proportional to the amount of methionine ingested (it will be recalled that the 50 p. 100 casein diet contained 1.5 p. 100 methionine), Cysta $S$ was enhanced mainly by high dietary protein, and Cysta $t$ was induced by both factors, but methionine exerted no additional effect in the presence of the high protein diet.

\section{Experiment 3. Hormonal factors}

As shown in figure 2, Ser DH activity was not greatly affected by hormones under our experimental conditions ; nevertheless, maximum activity (15-fold the control) was noted with high protein + methionine + cortisol.

The activity of MAdT depended mostly on the amount of substrate (methionine) ingested, while the inducers of Cysta $S$ in our experiment were, in decreasing order : the high protein diet, cortisol, and then methionine. Cysta $t$ activity was principally induced by a high protein diet, to a lesser extent by methionine, and not at all by cortisol or insulin.

\section{Discussion}

Our results show increased PEPCK activity and reduced PK activity under conditions favoring gluconeogenesis (fasting or a high protein diet, the latter was more effective). These results are in agreement with many other observations concerning 

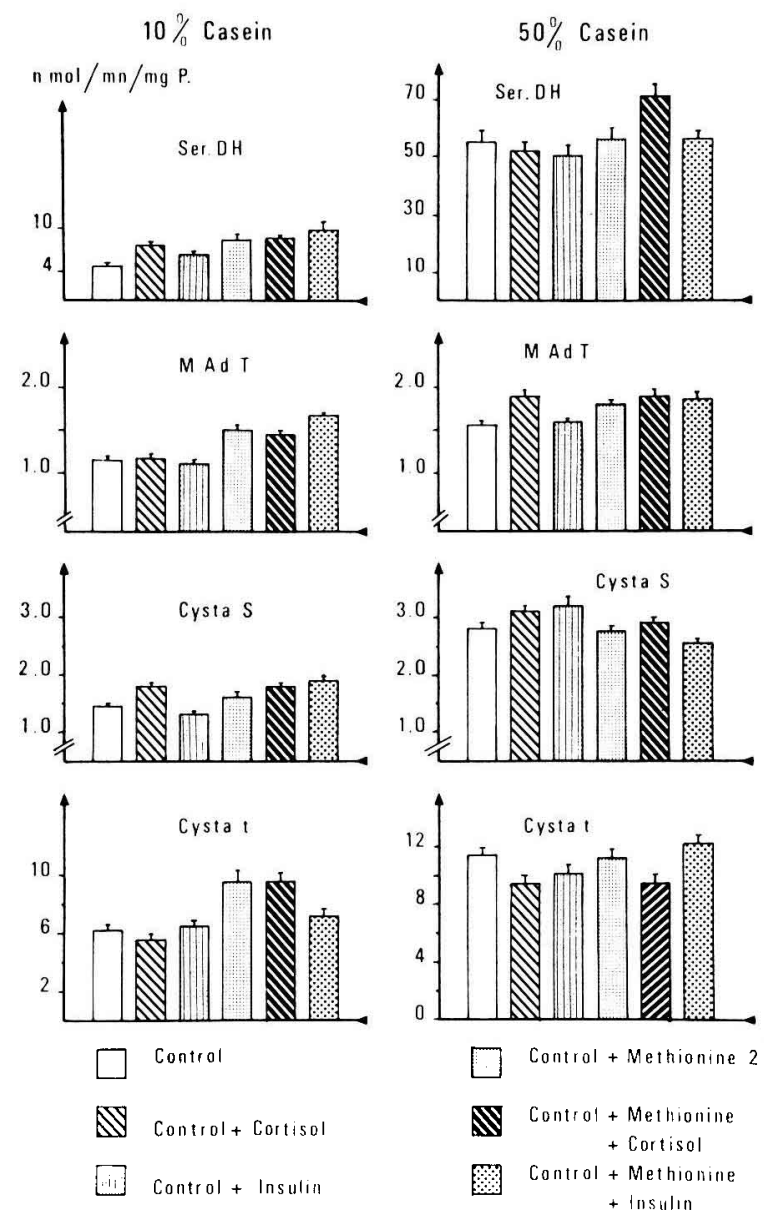

FIG. 2. - Hepatic enzyme activities following high cosein diets, cortisol and insulin administration and methionine excess ingesfed for three weeks. Values for each group (8 rats) represent means \pm SEM. Enzyme activities are expressed in nanomoles of substrate converted per minute per $\mathrm{mg}$ protein at $37^{\circ} \mathrm{C}$.

the regulation of glucose metabolism (Scrutton and Utter, 1968 ; Hanson and Garber, 1972 ; Romsos and Leveille, 1974 ; Peret and Chanez, 1976).

The high protein diet lowered the activities of all the enzymes involved in lipogenesis (G6PDH, AcCoA carbox, FAS) as reported by Vaughan and Winders (1964) and Szepesi and Freedland (1967). The behavior of G6PDH, strongly stimulated by the 50 p. 100 casein diet, as also reported in the literature (Szepesi and Freedland, 1967 ; 1969 ; Eggleston and Krebs, 1974), is distinctly different from that of the other lipogenic enzymes and may be a peculiarity of high casein diets (Peret et al., 1975).

Methionine strongly reduced the activity of ME, but at the same time the activities of the enzymes involved in lipid synthesis were unaffected ; as reported in the literature (Tepperman et al., 1968 ; Diamant and Shafrir, 1975 ; Stark et al., 1975), ME did 
not seem to be correlated with the other lipogenic enzymes. In our experiment, lipogenesis could utilize the NADPH produced by the pentose cycle (G6PDH, 6PGDH) when ME activity was reduced. On the other hand, gluconeogenesis (PEPCK) did not increase, while gycolysis (PK) was reduced; this phenomenon could be explained by a continuous "flow » of pyruvate coming from methionine degradation in adapted animals (Daniel and Waisman, 1969 ; Simpson and Freedland, 1975). In this hypothesis, the pyruvate formed would participate, via acetyl-CoA, in the Krebs cycle and/or lipogenesis, whose activity would be maintained. Only the determination of pyruvate, malate and citrate in the liver could confirm this hypothesis.

Our results concerning the normal enzyme activities involved in lipogenesis, even when excess methionine was ingested, are not in contradiction with those of Peretianu and Abraham (1964) who found that animals fed a mixed diet with excess methionine had less lipid in the liver and carcass. This phenomenon might be explained by supposing that the essential need for ATP in the first step of methionine catabolism could be partly met by glycolysis, and probably by a higher rate of lipolysis. At present, we have no data concerning in vivo lipogenesis or lipolysis under these conditions, but we intend to examine them.

As reported by many authors, Ser DH is induced by fasting (Goswami and Chatagner, 1966 ; Hoshino and Kröger, 1969), and with a high protein diet its activity remains high (Anderson ef al., 1968 ; Straub ef al., 1970 ; Ogura, 1970) because it is involved in the gluconeogenic processes. On the other hand, Ser DH is not necessary for, and is even detrimental to, methionine catabolism ; the low Ser DH activities found in this study show that animals ingesting methionine were enzymatically adapted to the excess. The high levels of activity found by some authors in the beginning of the adaptation period (Daniel and Waisman, 1969 ; Sanchez and Swendseid, 1969 ; Girard-Globa ef al., 1972) did not persist after 3 weeks; these activities in the first days of ingestion were probably due to a corticosterone release (Munro ef al., 1963 ; Peretianu, 1968), which is known to be an inducer of the Ser DH (Jost ef al., 1968 ; Ishikawa and Nakajima, 1970 ; Mohrenweiser and Yatvin, 1972).

The response of transsulfuration enzymes to methionine, their specific inducer, was very different.

In fasted animals, the amount of the essential free amino acids, particularly methionine, rises in plasma and liver (Adibi, 1971) ; the high activity found for MAdT in our study was a consequence of this accumulation. The fact that total Cysta $S$ activity in the liver decreased suggests a « sparing effect » to prevent excessive methionine catabolism, and favors de novo synthesis of methionine from homocysteine by betaine-homocysteine methyltransferase (Finkelstein and Kyle, 1968) or methyl-THFhomocysteine methyltransferase (Grzelakowska-Sztabert and Landman-Balinska, 1976).

Finkelstein (1967), studying these three enzymes, observed the same phenomenon, and the differences between our results and those of Pan and Tarver (1967) in the first two days of starvation are probably related to the higher dietary protein ingested by their rats before fasting.

Under our experimental conditions, MAdT activity was influenced only by the amount of dietary methionine (free or contained in proteins) ; cortisol or insulin had no effect. Finkelstein (1967) found that hydrocortisone increased MAdT activity after 
7 days of treatment; the results of Pan et al. $(1967,1968)$ and Shou et al. $(1969)$ also showed the intervention of corticoids, but these last experiments used very high amounts of hormones (4 times ours), which are pharmacologic and probably had an indirect effect on protein «turnover ».

Our results show that Cysta $S$ seems to be the most responsive enzyme of the pathway to hormones and nutritional status. The importance of its regulation was shown by Kato et al. (1966), Finkelstein et al., $(1967,1968)$ and Pan et al., (1971) ; it directs methionine metabolism toward catabolism or synthesis, mediated by the folate methylating pathway.

The results for Cysta $\dagger$ activity are in agreement with those in the literature (Trautmann and Chatagner, 1964; Durieu-Trautmann and Chatagner, 1966 ; Finkelstein, 1967) showing that nutritional factors are the best inducers of this enzyme. Based on the stereospecificity (de Billy et al., 1975) and the quaternary structure (Deme et al., 1972) of the enzyme, it is easy to imagine how complicated its regulation by direct or allosteric substrates might be.

We conclude that in adapted rats, the dietary factors used here (methionine and high protein diet) have stronger and more persistent effects than injected hormones on the regulation of both the specific and the non-specific metabolic pathways studied in this report. These animals need a lot of ATP for methionine catabolism, and they seem to generate this ATP from their own body lipids when the diet does not provide sufficient energy.

Important questions has been raised in this work. Does excess dietary methionine increase lipid «turnover »? Can methionine be used to direct animal metabolism toward lipolysis? Studies in progress will attemp to answer these questions.

Reçu en Juillet 1978.

Accepté en septembre 1978.

Résumé. Trois expériences ont été effectuées pour comparer l'influence de facteurs nutritionnels : le jeûne, un régime à $50 \mathrm{p}$. 100 de protéines, et un excès de méthionine, et de facteurs hormonaux, cortisol et insuline, sur les activités de certaines enzymes de la transsulfuration, de la glycolyse, de la néoglucogenèse, du catabolisme protéique et de la lipogenèse, chez des rats adultes adaptés aux régimes expérimentaux.

Si l'activité de la Méthionine-Adénosyl Transférase (MAdT) semble dépendre directement de la quantité de méthionine ingérée, celle de la Cystathionine Synthase (Cysta S.) est surtout sensible aux facteurs hormonaux, et l'activité de la cystathionase (Cysta t.) d'abord aux facteurs nutritionnels. Quand des rats sont soumis à un excès alimentaire de méthionine, l'activité de la pyruvate kinase (PK) diminue, et celle de l'enzyme malique est fortement réduite, alors que les autres enzymes impliquées dans la lipogenèse gardent des activités normales. Une hypothèse concernant ce dernier phénomène est avancée.

Dans nos conditions expérimentales, les facteurs alimentaires ont montré des effets plus importants et plus durables que ceux des hormones injectées, sur les voies métaboliques étudiées, spécifiques ou non spécifiques de la méthionine.

\section{References}

ADIBI S. A., 1971. Interrelationship between level of amino acids in plasma and tissues during sfarvation. Amer. J. Physiol., 221, 829-838. 
ANDERSON H. L., BENEVEGA N. J., HARPER A. E., 1968. Associations among food and protein intake, serine dehydratase, and plasma amino acids. Amer. J. Physiol., 214, 1008-1013.

CHANG H. C., LANE M. D., 1966. The enzymatic carboxylation of phosphoenolpyruvate. J. biol. Chem., 241, 2413-2420.

CHANG H. C., SEIDMAN I., TEEBAR G., LANE M. D., 1967. Liver acelyl CoA carboxylase and fatty acid synthetase. Relative activities in the normal state and in hereditary obesity. Biochem. Biophys. Res. Commun., 28, 682-686.

CHOU T. C., LOMBARDINI J. B., 1972. A rapid assay procedure for ATP : L-methionine adenosyl transferase. Biochim. biophys. Acta, 276, 399-406.

DANIEL R. G., WAISMAN H. A., 1969. Adaptation of the weanling rat to diets containing excess methionine. J. Nutr., 99, 299-306.

DE BILLY G., MULLER P., CHATAGNER F., 1975. New insights into the active center of rat liver cystathionase. Biochim. Biophys. Acta, 397, 231-243.

DEME D., de BILLY G., CHATAGNER F., 1972. Effect of sodium dodecyl sulfate on rat liver homoserine dehydratase. Biochimie, 54, 1089-1092.

DIAMANT S., SHAFRIR E., 1975. Modulation of the activity of insulin dependant enzymes of lipogenesis by glucocorticoïds. Eur. J. Biochem., 53, 541-546.

DURIEU-TRAUTMANN O., CHATAGNER F., 1966. Influence de l'éthionine ef des hormones glucocorticoïdes sur la cystathionase du foie du rat. Bull. Soc. Chim. biol., 48, 77-87.

EGGLESTON L. V., KREBS H. A., 1974. Regulation of pentose phosphate cycle. Biochem. J., 138, 425435.

FALLON H. J., HACKNEY E. J., BYRNE W. L., 1966. Serine biosynthesis in rat liver. Regulation of enzyme concentration by dietary factors. J. biol. Chem., 241, 4157-4167.

FINKELSTEIN J. D., 1967. Methionine metabolism in mammals. Effects of age, diet and hormones on three enzymes of the pathway in rat tissues. Arch. Biochem. Biophys., 122, 583-590.

FINKELSTEIN J. D., MUDD S. H., 1967. Transsulfuration in mammals. The methionine-sparing effect of cystine. J. biol. Chem., 242, 873-880.

FINKELSTEIN J. D., KYLE W. E., 1968. Ethanol effects on methionine metabolism in rat liver. Proc. Soc. exp. Biol. Med., 129, 497-501.

FINKELSTEIN J. D., KYLE W. E., HARRIS B. J., 1974. Methionine metabolism in mammals : regulatory effects of S-adenosylhomocysteine. Arch. Biochem. Biophys., 165, 774-779.

FITCH W. M., HILL R., CHAIKOFF 1. L., 1959. The effect of fructose feeding on glycolytic enzyme activities of the normal rat liver. J. biol. Chem., 234, 1048-1051.

GIRARD-GLOBA A., ROBIN P., FORESTIER M., 1972. Long term adaptation of weanling rats to high dietary levels of methionine and serine. J. Nutr., 102, 209-218.

GOSWAMI M. N. D., CHATAGNER F., 1966. Starvation induced adaptation of rat liver tyrosine transaminase and serine dehydratase. Experientia, 22, 370-371.

GREENBERG D. M., 1962. Cystathionine and homoserine cleavage. In COLOWICK S. P., KAPLAN N. O. Methods in enzymology, vol. 5, 936-942, Acad. Press, New York.

GRZELAKOWSKA-SZTABERT B., LANDMAN-BALINSKA M., 1976. Regulation of methionine synthetase in L-cells by vitamin B-12, folate and methionine. Biochem. Soc. Trans., 4, 922-925.

HANSON R. W., GARBER A. J., 1972. Phosphoenolpyruvate carboxykinase. I. Its role in gluconeogenesis. Amer. J. clin. Nutr., 25, 1010-1021.

HOSHINO J., KROGER H., 1969. Properties of L-serine dehydratase purified from rat liver after induction by fasting or feeding casein hydrolysate. Hoppe-Seyler's Z. Physiol. Chem., 350, $595-$ 602.

HSU R. Y., LARDY H. A., 1969. Malic enzyme. In LOWENSTEIN J. M., Methods in enzymology, vol. 17, 230-235, Acad. Press, New York.

HUBBEL R. B., MENDEL I. B., WAKEMAN A. J., 1937. A new salt mixture for use in experimental diets. J. Nutr., 14, 273-275.

ISHIKAWA E., NAKAJIMA K., 1970. Hormonal and dietary control of enzymes in the rat. I Roles of the pancreas and the adrenal in the regulation of liver serine dehydratase activity. J. Bioch. (Jopan). 67, 685-692.

JOST J. P., KHAIRALLAH E. A., PITOT H. C., 1968. Studies on the induction and repression of enzymes in rat liver. $V$. Regulation of the rate of synthesis and degradation of serine dehydratase diefary aminoacids and glucose. J. biol. Chem., 243, 3057-3066. 
KATO A., OGURA M., SUDA M., 1966. Control mechanism in the rat liver enzyme system converting L-methionine to L-cystine. III. Non competitive inhibition of cystathionine synthetaseserine dehydratase by elemental sulfur competitive inhibition of cystathionase-homoserine dehydratase by L-cysteine and L-cystine. J. Bioch. (Japan), 59, 40-48.

KREBS H. A., HEMS R., TYLER B., 1976. The regulation of folate and methionine metabolism. Bioch. J., 158, 341-313.

MAEDA H., IKEDA I., SUGANO M., 1975. Behavior of liver lipogenesis enzymes in rat fed threonine imbalanced diet. Nutr. Rep. Int., 12, 61-67.

MCKENZIE R. M., GHOLSON R. K., 1973. A simple assay for methionine adenosyltransferase using cation exchange paper and liquid scintillation spectrometry. Analyt. Bioch., 53, 384-391.

MOHRENWEISER H. W., YATVIN M. B., 1972. Regulation of serine dehydratase induction in rat liver. Proc. Soc. exp. Biol. Med., 141, 1084-1088.

MUDD H. S., FINKELSTEIN J. D., IRREVERRE F., LASTER I., 1965. Transulfuration in mammals. Microassays and tissue distributions of the three enzymes of the pathway. J. Biol. Chem., 240, 4382-4392.

MUNRO H. N., STEELE M. H., HUTCHISON W. C., 1963. Blood corticosteronelevels in the rat after administration of amino-acids. Noture, 199, 1182-1183.

OGURA M., 1970. On the relationship between food composition and serine dehydratase activity in rat liver. Part II. On the factor of enzyme induction by high protein diet. Agr. biol. Chem., 34, 585-589.

PAN F., TARVER H., 1967. Effects of diet and other factors on methionine adenosyltransferase levels in rat liver. J. Nutr., 92, 274-280.

PAN F., CHANG G. G. LEE S. C., 1968. Induction of methionine adenosyl transferase in rat liver by corticosteroids. Proc. Soc. exp. Biol. Med., 128, 611-616.

PAN F., CHIN S-HF., PAI S. H., 1971. Glucagon and glucocorticoids in the regulation of rat liver cystathionine synthetase activity. Endocrinology 88, 723-729.

PERET J., CHANEZ M., 1976. Influence of diet, cortisol and insulin on the activity of pyruvate carboxylase and phosphoenolpyruvate carboxykinase in the rat liver. J. Nutr., 106, 103-110.

PERET J., MACAIRE I., CHANEZ M., 1973. Schedule of protein ingestion nitrogen and energy utilization and circadian rhythm of hepatic glycogen, plasma corticosterone and insulin in rats. J. Nutr., 103, 866-874.

PERET J., CHANEZ M., COTA J., MACAIRE I., 1975. Effect of quantity and quality of dietary protein and variation in cerfain enzyme activities on glucose metabolism in the rat. J. Nutr., 105, 15251534.

PERETIANU J., 1968. Teneur en corticosterone du sang et des surrénales chez le rat nourri avec un régime contenant un excès de méthionine. Arch. Sci. physiol., 22, 441-447.

PERETIANU J., ABRAHAM J., 1964. Le phénomène de déséquilibre par excès d'un acide aminé : étude des effets supplétifs de la méthionine selon les modalités de son emploi en régime mixte ou en alimentation séparée. I. Cas de la caséine. Arch. Sci. physiol., 18, 253-264.

ROMSOS D. R., LEVEILLE G. A., 1974. Effect of diet on activity of enzymes involved in fatty acid and cholesterol synthetis. Adv. Lipid Res., 12, 97-146.

SANCHEZ A., SWENDSEID M. E., 1969. Amino-acid levels and enzyme activity in tissues of rats force-fed diets differing in methionine content. J. Nutr., 99, 145-151.

SCRUTTON M. C., UTTER M. F., 1968. Regulation of glycolysis and gluconeogenesis in animal tissues. Ann. Rev. Bioch., 37, 249-302.

SHOU L., PAN F., CHIN S.-F., 1969. Pancreatic hormones and hepatic methionine adenosyltransferase in the rat. Proc. Soc. exp. Biol. Med., 131, 1012-1018.

SIMPSON R. C., FREEDLAND R. A., 1975. Relative importance of the two major pathways for the conversion of cysteine. J. Nutr., 105, 1440-1446.

SNEDECOR G. W., 1956. Statistical methods, 5th ed., lowa State Univ. Press, Ames.

STARK M. J., THOMPSON B., FRENKEL R., 1975. Possible alternative functions of rat liver malic enzyme. Arch. Biochem., Biophys., 166, 174-180.

STRAUB K., JENNISSEN H., KROGER H., 1970. Zur regulation der L-serin dehydratase in der rattenleber. V, ges. esp. Med., 152, 294-305.

SUDA M., NAKAGAW H., 1971. Serine dehyratase (rat liver). In TABOR H., TABOR C. W. Methods in enzymology, vol. 17 (part b), 346-351. Acad. Press, New York. 
SZEPESI B., FREEDLAND R. A., 1967. Alterations in the activities of several rat liver enzymes at various times after initiation of a high protein regimen. J. Nutr., 93, 301-306.

SZEPESI B., FREEDLAND R. A., 1969. A possible method of estimating hormones effects on enzyme synthesis. Arch. Biochem. Biophys., 133, 60-69.

TEPPERMAN H. M., de la GARZA S. A. TEPPERMAN, 1968. Effects of dehydroepiandrosterone and diet protein on liver enzymes and lipogenesis. Amer. J. Physiol., 214, 1126-1132.

TRAUTMANN O., CHATAGNER F., 1964. Adaptation méłabolique de la cystathionase du foie de rat. Bull. Soc. Chim. biol., 46, 129-139.

VAUGHAN D. A., WINDERS R. L., 1964. Effects of diet on HMP dehydrogenase and malic (TPN) dehydrogenase in the rat. Amer. J. Physiol., 206, 1081-1084.

WEBER G., STAMM N. B., FISHER E. A., 1965. Insulin inducer of pyruvate kinase. Science, 149, 65-67. 